\title{
EFFECTS OF EUCALYPTOL ON HOUSE FLY (DIPTERA: MUSCIDAE) AND BLOW FLY (DIPTERA: CALLIPHORIDAE)
}

\author{
Kabkaew L. SUKONTASON, Noppawan BOONCHU, Kom SUKONTASON \& Wej CHOOCHOTE
}

\begin{abstract}
SUMMARY
The effects of eucalyptol were evaluated against the house fly, Musca domestica L., and blow fly, Chrysomya megacephala (F.). The bioassay of adults, using topical application, indicated that $M$. domestica males were more susceptible than females, with the $\mathrm{LD}_{50}$ being 118 and $177 \mu \mathrm{g} / \mathrm{fly}$, respectively. A higher $\mathrm{LD}_{50}$ of $C$. megacephala was obtained; $197 \mu \mathrm{g} / \mathrm{fly}$ for males and $221 \mu \mathrm{g} / \mathrm{fly}$ for females. Living flies of both species yielded a shorter life span after being treated with eucalyptol. The bioassay of larvae, using the dipping method on the third instar, showed that $M$. domestica was more susceptible than $C$. megacephala, with their $\mathrm{LC}_{50}$ being 101 and $642 \mu \mathrm{g} / \mu \mathrm{l}$, respectively. The emergence of adults, which had been treated with eucalyptol in larvae, decreased only in M. domestica. Having the volatile property, fumigation or impregnated paper test of eucalyptol or the efficacy of repellence or attractiveness merits further investigations to enhance bio-insecticidal efficacy.
\end{abstract}

KEYWORDS: Musca domestica; Chrysomya megacephala; Eucalyptol; Bio-insecticide.

\section{INTRODUCTION}

The common house fly, Musca domestica L., and blow fly, Chrysomya megacephala (F.), are medically important insects; being mechanical carriers of several pathogens (e.g., virus, bacteria, protozoa, helminth eggs) that may cause illness and disease in humans ${ }^{4}$ or annoyance to humans and agronomic livestock. The economic loss in livestock business resulting from fly annoyance and/or myiasis caused by these species has been recorded ${ }^{23}$.

A conventional method for fly control in the short-term is the use of insecticides. Nevertheless, the widespread and massive applications of chemical insecticides frequently produce the risk of developing insect resistance and insecticidal residual for humans and the environment. Accordingly, bio-insecticides, a botanical type based on natural compounds from plants, are expected to be a possible application as selective, efficacious and toxicologically safe insecticides. Several reports have shown the efficacy of natural compounds on insects ${ }^{6,8}$. As for flies, the majority have been found to assess crude extracts from many botanical sources. Regarding this, assessment of the pure active compound extracted from plants against flies is of interest.

Eucalyptol or 1,8-cineole, the major component of eucalyptol oil and other plants, is a monoterpene substances. Eucalyptol is safe for humans, and has been used as medicine and aromatherapy for a long time ${ }^{20}$. According to the primarily lipophilic property, several monoterpenoids have been reported as having toxic capability to herbivore insects, and were therefore considered as a potential, alternative biopesticide. Toxicity of eucalyptol on several species of medical or economical insects (e.g., triatomine bug, red flour beetle, lessor grain borer, rice weevil, sawtoothed grain beetle, house fly, Hessian fly, German cockroach, and stored food mite) have been recorded ${ }^{8-10,14,20}$. We therefore examined the effect of eucalyptol on $M$. domestica and C. megacephala to provide the knowledge for natural products in fly control.

\section{MATERIALS AND METHODS}

Collection and maintenance of flies: The colonies of $M$. domestica and $C$. megacephala originated from adults collected from markets in Muang district, Chiang Mai province, northern Thailand, using a sweeping net. They were transferred into a small cage $(16 \times 16 \times 16 \mathrm{~cm})$ and transported to the Department of Parasitology, Faculty of Medicine, Chiang Mai University, for identification and colonization. Before identification, the flies were anesthetized by placing the cages in a refrigerator set at $4{ }^{\circ} \mathrm{C}$ for $15 \mathrm{~min}$. The anesthetized flies were identified following the taxonomic keys ${ }^{7,21}$. M. domestica and C. megacephala were segregated into separate cages $(30 \times 30 \times 30 \mathrm{~cm})$ screened with black cloth. Adults of both species were reared with two kinds of food; (I) mixture of $10 \%(\mathrm{w} / \mathrm{v})$ sugar solution at $985 \mathrm{ml}$ and multivitamin syrup at $15 \mathrm{ml}$; and (II) fresh pork liver as both a food source and oviposition site. Furthermore, $M$. domestica flies were provided with a combination of rice polish, chaff and water at a weight ratio of $2: 1: 1$, and $40 \mathrm{~g}$ of this mixture was placed on a $9 \mathrm{~cm}$ glass plate, as a supplementary food and oviposition site. Small pieces of fresh pork liver were changed daily, 


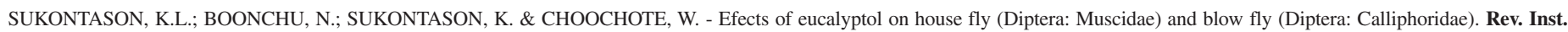
Med. trop. S. Paulo, 46(2):97-101, 2004.

while the mixture of $10 \%$ sugar solution, multivitamin syrup and the supplementary food, were changed every two days. Subsequently, the oviposition sites were observed daily for the presence of fly eggs; and if present, they were transferred into a $12 \times 15 \times 6 \mathrm{~cm}$ transparent plastic box, and $40 \mathrm{~g}$ of fresh pork liver was provided as larval food. To prevent over population, each box housed 30-40 larvae. The lids of the box were rectangular, cut to $3 / 4$ of the total area and used together with the finest silk screen cloth for ventilation and the prevention of small insects entering to oviposit. The boxes were covered by the lids and both were sealed tightly with adhesive paper tape to prevent the larvae crawling out. These boxes were kept under room temperature $\left(24-28{ }^{\circ} \mathrm{C}\right)$ in a cabinet at the rearing room of the Department of Parasitology. Liver was replaced daily until some third instars developed into prepupa, the nonfeeding period. The box having pupae was still covered and tightly sealed until some pupae emerged as adults. Then, the box containing some adults was placed into a rearing cage and the adults released. The next generation of flies was reared in the same manner as previously described. Flies after the eighth generation were graded as the laboratory colony and used to assess the toxicity of eucalyptol.

Assessment of eucalyptol toxicity: The commercial eucalyptol was purchased from Sigma-Aldrich ${ }^{\circledR}$ (Switzerland). This eucalyptol was produced for R\&D (Research and Development) use only, not for drug, household or other uses. Its properties were $98 \%$ purity and $0.92 \mathrm{~g} / \mathrm{ml}$ of density. The bioassay was performed using the topical application method for adults ${ }^{22,27}$ and dipping method for larvae ${ }^{11}$. For topical application, 4-day-old adults were individually transferred from the rearing cage to a small cage $(16 \times 16 \times 16 \mathrm{~cm})$ using a transparent testtube. This cage was then covered with a transparent plastic bag in order to anesthetize the flies by fumigation with $5 \mathrm{~L}$ of $\mathrm{CO}_{2}$ for $3 \mathrm{~min}$. The flies were separated into males or females. Each sex was randomly divided into 7 groups of 20 flies per group and transferred into each small cage $(16 \times 16 \times 16 \mathrm{~cm})$ for recovery before being treated with eucalyptol. Eucalyptol solutions were immediately prepared in a small glass bottle by the serially 2 -fold dilution method using absolute ethanol as the solvent. The concentration series started at 100\%, 50\%, 25\%, $12.5 \%$ and $6.25 \%$ (v/v) of eucalyptol; denoting $0.902,0.451,0.226,0.113$ and $0.056 \mathrm{~g} / \mathrm{ml}$, respectively. All dilutions were mixed well by using an autopipette and then the bottles were tightly closed immediately with their caps. The flies in each group were re-anesthetized using $\mathrm{CO}_{2}$ fumigation prior to topical application. Anesthetized flies were gently placed onto a plastic ice cube, then $1.0 \mu \mathrm{l}$ of each diluted eucalyptol concentration was individually and topically applied at the dorsal thorax of each fly using a Hamilton Digital Microsyringe ${ }^{\mathrm{TM}}$ (USA).

Control flies were divided into 2 groups; treated with absolute ethanol and untreated. Both groups were anesthetized twice in a similar manner to that of the treated groups. After being tested, the flies in all groups were transferred into each rearing cage and provided with adult food. Mortality in each group was assessed at $24 \mathrm{~h}$ periods after exposure by softly stimulating each fly with the tip of a pen. Those flies that showed no response were considered dead. The experiments were carried out in three replications. The lethal dose (LD) of toxicity $\left(\mathrm{LD}_{50}, \mathrm{LD}_{95}\right.$ and $\left.\mathrm{LD}_{99}\right)$ was determined based on mortality data at $24 \mathrm{~h}$ assessments, and Probit analysis (Harvard Programming; $\mathrm{Hg} 1,2$ ) was used for analyzing the dosage-mortality response. Later, all living flies, both treated and controls, were studied further for their life span.
Life span of living flies after being topically tested with eucalyptol: After being tested with the same concentration of eucalyptol, all living flies were pooled together and maintained within the same cage. Food was provided, and the mortality of flies was investigated daily. All flies in the rearing cages were maintained under the same conditions including quality and quantity of food. Replacement of food was performed as previously described until all the flies were dead. The life span of the flies in each group was summarized and analyzed by comparing with controls using the Mann Whitney $U$ test.

Dipping method for the bioassay test of the larvae: The third instar, $M$. domestica and C. megacephala, used in this experiment were 3-dayold after hatching from the same egg batch. Each species was randomized into 7 groups (20 larvae/group) and reared in separate rearing boxes. Eucalyptol solutions were immediately prepared in a ceramic bowl by the serially 2-fold dilution method using absolute ethanol as the solvent, and the concentration was the same as that in the adult experiments. A bowl containing each concentration of eucalyptol was tightly covered with the lid until they were used for the dipping method. For the experiment, the larvae of each group were wrapped in a voile cloth and gently dipped into eucalyptol solution, whereas those of the controls were dipped in absolute ethanol. After being dipped for exactly $30 \mathrm{sec}$, the larvae were transferred to the rearing box containing food. The mortality of each larva was assessed at $24 \mathrm{~h}$ by touching each one with a paint brush (no. 0), and those not responding were considered dead. The dipping experiments were carried out in three replications. The $\mathrm{LD}_{50}, \mathrm{LD}_{95}$ and $\mathrm{LD}_{99}$ of toxicity was determined based on mortality data at $24 \mathrm{~h}$ assessments, and Probit analysis (Harvard Programming; $\mathrm{Hg} 1,2$ ) was used in analyzing the dosagemortality response. Living larvae were studied further for their adult emergence after being tested with eucalyptol.

Emergence of adults after being dipped with eucalyptol: Living larvae were reared in each rearing box after being dipped in each concentration of eucalyptol or absolute ethanol, and the maintenance of the larvae was conducted in the same manner as previously described until emergence. Once emergence occurred, the adult flies were counted. The Chi Square test was used to compare the emergence of treated and control groups.

\section{RESULTS}

Assessment of eucalyptol toxicity: The eucalyptol toxicities against adult $M$. domestica and $C$. megacephala, evaluated by $\mathrm{LD}_{50}, \mathrm{LD}_{95}$ and $\mathrm{LD}_{99}$ values, are presented in Table 1 . Regarding $M$. domestica, all were dead after they had been treated with eucalyptol $0.902 \mathrm{~g} / \mathrm{ml}$. Males were more susceptible than females in all concentrations used. The $\mathrm{LD}_{50}$ and $\mathrm{LD}_{95}$ of males were 118 and $460 \mu \mathrm{g} / \mathrm{fly}$, respectively, whereas those of females were 177 and $500 \mu \mathrm{g} / \mathrm{fly}$, respectively. No significant difference was found between males and females, based on the overlapping of $95 \%$ confidence interval at $\mathrm{LD}_{50}$. As for $C$. megacephala, toxicity of eucalyptol against males was slightly lower than females. The $\mathrm{LD}_{50}$ and $\mathrm{LD}_{95}$ of males were 197 and $380 \mu \mathrm{g} / \mathrm{fly}$, respectively, while in females, they were 221 and $422 \mu \mathrm{g} / \mathrm{fly}$, respectively. No significant difference in mortality between males and females was detected.

Life span of living flies after being topically tested with eucalyptol: The median life span of adults in each group is shown in Table 2. No living flies of $M$. domestica and $C$. megacephala were found after being 


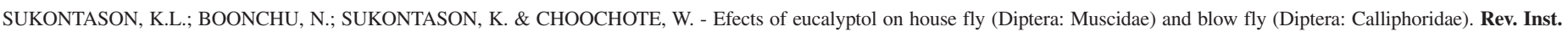
Med. trop. S. Paulo, 46(2):97-101, 2004.

Table 1

Toxicity of eucalyptol against adult Musca domestica and Chrysomya megacephala using topical application

\begin{tabular}{|c|c|c|c|c|c|c|}
\hline \multirow[t]{2}{*}{ Sex } & \multicolumn{3}{|c|}{ M. domestica } & \multicolumn{3}{|c|}{ Chrysomya megacephala } \\
\hline & $\mathrm{LD}_{50}(95 \% \mathrm{CI})$ & $\mathrm{LD}_{95}(95 \% \mathrm{CI})$ & $\mathrm{LD}_{99}(95 \% \mathrm{CI})$ & $\mathrm{LD}_{50}(95 \% \mathrm{CI})$ & $\mathrm{LD}_{95}(95 \% \mathrm{CI})$ & $\mathrm{LD}_{99}(95 \% \mathrm{CI})$ \\
\hline Male & $118(91-154)$ & $460(354-598)$ & 987 (759-1283) & $197(177-218)$ & $380(323-495)$ & $549(435-816)$ \\
\hline Female & $177(153-202)$ & $500(392-754)$ & $895(623-1682)$ & $221(199-244)$ & $422(357-560)$ & $608(478-924)$ \\
\hline
\end{tabular}

Unit of mortality is $\mu \mathrm{g} / \mathrm{fly}$.

Table 2

Life span of living flies [median (range)] after being topically tested with varying concentrations of eucalyptol

\begin{tabular}{|c|c|c|c|c|}
\hline \multirow{2}{*}{$\begin{array}{l}\text { Concentration of } \\
\text { eucalyptol }(\mathrm{g} / \mathrm{ml})\end{array}$} & \multicolumn{2}{|c|}{ M. domestica (Days) } & \multicolumn{2}{|c|}{ C. megacephala (Days) } \\
\hline & Male & Female & Male & Female \\
\hline 0.451 & - & $2(2-3)^{*}$ & $5(2-8)^{*}$ & $6(2-12)^{*}$ \\
\hline 0.226 & $5(2-17)^{*}$ & $4(2-18)^{*}$ & $7(2-16)^{*}$ & $12(3-21)^{*}$ \\
\hline 0.113 & $8(2-19)^{*}$ & $8(2-20)^{*}$ & $12(2-31)^{*}$ & $13(4-30)^{*}$ \\
\hline 0.056 & $13(3-33)^{* *}$ & $17(5-29)^{* *}$ & $15(4-48)^{* * *}$ & $20(4-49)^{* * *}$ \\
\hline Absolute ethanol & $15(2-30)^{* * *}$ & $15.5(2-33)^{* * *}$ & $19.5(3-49)^{* * *}$ & $19.5(2-49)^{* * *}$ \\
\hline Natural control & $17(2-31)$ & $17(2-31)$ & $21(3-49)$ & $23(2-50)$ \\
\hline
\end{tabular}

${ }^{*}$ Significant difference from control group (absolute ethanol) (Mann Whitney $U$ test, $p<0.05$ ); ${ }^{* *}$ No significant difference from control group (absolute ethanol) (Mann Whitney $U$ test, $p>0.05$ ); ${ }^{* * *}$ No significant difference from natural control (Mann Whitney $U$ test, $p>0.05$ ).

topically tested with eucalyptol at $0.902 \mathrm{~g} / \mathrm{ml}$. In those treated with eucalyptol at $0.451 \mathrm{~g} / \mathrm{ml}$, only male $M$. domestica died. No significant difference in median life span was detected between males treated with eucalyptol at $0.056 \mathrm{~g} / \mathrm{ml}$ and those receiving absolute ethanol (Mann Whitney $U$ test, $p=0.791$ ). However, the median life span of males treated with eucalyptol at 0.226 and $0.113 \mathrm{~g} / \mathrm{ml}$ differed significantly from those receiving absolute ethanol (Mann Whitney $U$ test, $p=0.003$ and $p=0$, respectively). There was no significant difference in median life span between females treated with eucalyptol at $0.056 \mathrm{~g} / \mathrm{ml}$ and those receiving absolute ethanol (Mann Whitney $U$ test, $p=0.987$ ). However, the median life span of females treated with eucalyptol at 0.451 , 0.226 and $0.113 \mathrm{~g} / \mathrm{ml}$ differed significantly from those receiving absolute ethanol (Mann Whitney $U$ test, $p=0.006, p=0$ and $p=0$, respectively).

For C. megacephala, the life span of flies treated with the same concentration of eucalyptol was similar to those of $M$. domestica. No significant difference in median life span was detected between males treated with eucalyptol at $0.056 \mathrm{~g} / \mathrm{ml}$ and those receiving absolute ethanol (Mann Whitney $U$ test, $p=0.112$ ). However, the median life span of males treated with eucalyptol at $0.451,0.226$ and $0.113 \mathrm{~g} / \mathrm{ml}$ differed significantly from those receiving absolute ethanol (Mann Whitney $U$ test, $p=0.015, p=0$ and $p=0$, respectively). No significant difference in median life span was found between females treated with eucalyptol at $0.056 \mathrm{~g} / \mathrm{ml}$ and those receiving absolute ethanol (Mann Whitney $U$ test, $p=0.548$ ), but those subjected to eucalyptol at $0.451,0.226$ and $0.113 \mathrm{~g} / \mathrm{ml}$ differed significantly from those receiving absolute ethanol (Mann Whitney $U$ test, $p=0.032, p=0.002$ and $p=0$, respectively).

Dipping method for the bioassay test of the larvae: The results of the dipping method on third instar are presented in Table 3. The $\mathrm{LD}_{50}$ and $\mathrm{LD}_{95}$ of $M$. domestica were 101 and $239 \mu \mathrm{g} / \mu \mathrm{l}$, respectively, whereas, they were 642 and 1,539 $\mu \mathrm{g} / \mu \mathrm{l}$, respectively in C. megacephala. There was a significant difference between the $\mathrm{LD}_{50}$ of $M$. domestica and that of $C$. megacephala. The $\mathrm{LD}_{50}$ of $M$. domestica was lower.

\section{Table 3}

Toxic activity of eucalyptol against the third instar, $M$. domestica and C. megacephala, using the dipping method

\begin{tabular}{|c|c|c|c|}
\hline Species & $\begin{array}{c}\mathrm{LD}_{50}(95 \% \mathrm{CI}) \\
\mu \mathrm{g} / \mu \mathrm{l}\end{array}$ & $\begin{array}{c}\mathrm{LD}_{95}(95 \% \mathrm{CI}) \\
\mu \mathrm{g} / \mu \mathrm{l}\end{array}$ & $\begin{array}{c}\mathrm{LD}_{99}(95 \% \mathrm{CI}) \\
\mu \mathrm{g} / \mu \mathrm{l}\end{array}$ \\
\hline M. domestica & $\begin{array}{c}101 \\
(92-111)\end{array}$ & $\begin{array}{c}239 \\
(203-305)\end{array}$ & $\begin{array}{c}388 \\
(305-558)\end{array}$ \\
\hline C. megacephala & $\begin{array}{c}642 \\
(585-710)\end{array}$ & $\begin{array}{c}1539 \\
(1272-2044)\end{array}$ & $\begin{array}{c}2511 \\
(1915-3797)\end{array}$ \\
\hline
\end{tabular}

Emergence of adult flies after being dipped with eucalyptol: After the larvae had been dipped, they were reared to determine the success of emergence. As shown in Table 4, all M. domestica larvae died when they had been dipped in eucalyptol at $0.902 \mathrm{~g} / \mathrm{ml}$, thus no emergence of flies was found. When the larvae had been subjected to eucalyptol at $0.451,0.226,0.113$ and $0.056 \mathrm{~g} / \mathrm{ml}$, emergence was $50,67,35$ and $60 \%$, respectively. In contrast, the emergence of $C$. megacephala after the larvae had been dipped with eucalyptol at $0.902,0.451,0.226,0.113$ and 0.056 $\mathrm{g} / \mathrm{ml}$ was $100,93,90,93$ and $73 \%$, respectively.

\section{DISCUSSION}

Our study shows that both the adults and larvae of $M$. domestica were more significantly susceptible than $C$. megacephala to eucalyptol. The reason for such a difference between species was unknown. It might 


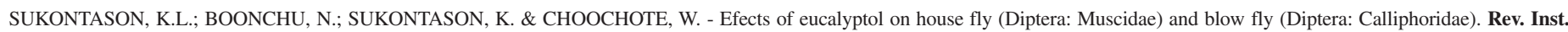
Med. trop. S. Paulo, 46(2):97-101, 2004.

Table 4

Emergence of $M$. domestica and $C$. megacephala after larvae had been dipped with eucalyptol

\begin{tabular}{lcc}
\hline Concentration $(\mathrm{g} / \mathrm{ml})$ & \multicolumn{2}{c}{$\%$ emergence } \\
& M. domestica & C. megacephala \\
\hline 0.902 & - & $100(15 / 15)$ \\
0.451 & $50(1 / 2)$ & $93(42 / 45)$ \\
0.226 & $67(2 / 3)$ & $90(53 / 59)$ \\
0.113 & $35(9 / 26)^{*}$ & $93(55 / 59)$ \\
0.056 & $60(31 / 52)^{*}$ & $73(44 / 60)^{* * *}$ \\
Absolute ethanol & $92(55 / 60)$ & $80(48 / 60)$ \\
Natural control & $93(56 / 60)$ & $68(41 / 60)$ \\
\hline
\end{tabular}

* Significant difference from control groups (Chi-square test, $p<0.05$ );

** Significant difference from the tested groups (Chi-square test, $\mathrm{p}<0.05$ )

be due to morphological difference, as suggested by BROWN \& $\mathrm{PAL}^{2}$. Adult $C$. megacephala is larger than M. domestica; $8-11 \mathrm{~mm}$ and 6-9 $\mathrm{mm}$, respectively ${ }^{23}$. Similarly, toxicity of eucalyptol in male $M$. domestica was more than in females. This was in accordance with several insecticide bioassay tests of house flies ${ }^{2}$. The difference in susceptibility is partly due to the smaller size of males ${ }^{2}$. The $\mathrm{LC}_{50}$ of house flies in this result (118 $\mu \mathrm{g} /$ fly in males and $177 \mu \mathrm{g} / \mathrm{fly}$ in females) was higher than that applied with the volatile oils, Matricaria chamomilla L. and Clerodendron inerme $\mathrm{G}$., on adult $M$. domestica, with the $\mathrm{LC}_{50}$ of the former and latter being 76 and $84 \mu \mathrm{g} / \mathrm{fly}$, respectively ${ }^{18}$. In contrast, the $\mathrm{LC}_{50}$ eucalyptol was lower than that of several monoterpenoids against $M$. domestica using the topical application $\left(\mathrm{LD}_{50} \approx 200\right.$ or $\left.>500 \mu \mathrm{g} / \mathrm{fly}^{15}\right)$. Recently, the screening test of eucalyptol, performed using the fumigation method, indicated that a concentration of $50 \mu \mathrm{g} / \mathrm{ml}$ air caused $100 \%$ mortality in adult $M$. domestica ${ }^{10}$. It might be that the fumigation method was more appropriate for a bioassay test of eucalyptol against $M$. domestica or other flies, and this merits investigation. Moreover, other efficacy of repellent or attractiveness to flies is of interest. Some documents have been found on repellent to cockroaches ${ }^{12}$ or attractiveness toward the banana weevil, Cosmopolites sordidus (Germar) ${ }^{13}$, grasshopper, Hypochlora alba (Dodge) ${ }^{1}$ and Mexican fruit fly, Anastrepha ludens (Loew) ${ }^{16}$.

Adult flies that had been topically tested with eucalyptol yielded a shorter life span; both sexes of M. domestica and C. megacephala were resembled. An increased concentration of eucalyptol resulted in shorter longevity; adults subjected to eucalyptol at $115 \mu \mathrm{g} / \mathrm{fly}$ produced a $\approx 2$ fold shorter life span. Although this was evident in the laboratory, shorter longevity would decrease the vectorial capacity of both sexes as far as the capacity of being a mechanical carrier was concerned ${ }^{19}$. Likewise, the shorter life span of flies in this experiment agreed with EL-SHAZLY et $a l .^{3}$, in that dipping a second instar of the false stable fly, Muscina stabulans (Fallén), in an extract of Nerium oleander L. decreased the adult survival rate $\approx 2$-fold. Moreover, this could prolong larval and pupal developmental rates, and decrease adult emergence. TRIPATHI et al. ${ }^{20}$ contributed the reduction of growth rate and food consumption in the adult red flour beetle, Tribolium castanaeum (Herbst), which was subjected to 1,8-cineole. Eucalyptol has been documented as suppressing the hatching of $T$. castanaeum and reducing the subsequent survival rate of larvae ${ }^{20}$. Regarding this, such potentially reproductive aspects are therefore needed for further investigation of flies.
Eucalyptol yielded a moderate larvicide effect $\left(\mathrm{LD}_{50}=101 \mu \mathrm{g} / \mu \mathrm{l}\right)$ on the larvae, M. domestica, while it was low against $C$. megacephala $\left(\mathrm{LD}_{50}=\right.$ $642 \mu \mathrm{g} / \mu \mathrm{l})$. The low toxicity in this study was similar to that of LAURENT et al..$^{9}$ in that the commercially pure compound of eucalyptol (1,8-Cineole) had a weak larvicidal action on the fourth instar nymph of the triatomine bug, Triatoma infestans (Klug), when topical application was used.

Although the toxicity of eucalyptol against the adults or larvae of flies varied from low to moderate in this study, some modes might enhance insecticidal toxicity. The small addition of compounds, called synergist, enormously increased toxicity ${ }^{11}$. D-limonene, the component of citrus peel oil extract, was synergized by piperonyl butoxide. When combined, these compounds produced a synergistic ratio of 3.2 and more rapid mortality of the adult cat fleas, Ctenocephalides felis (Bouché) 5 . Regarding this, a combination of eucalyptol with synergist, either from plant extract or commercial products, is a subject of interest.

\section{RESUMO}

\section{Efeitos do eucaliptol sobre a mosca doméstica (Diptera: Muscidae) e mosca varejeira (Diptera: Calliphoridae)}

Foram avaliados os efeitos do eucaliptol contra a mosca doméstica, Musca domestica L. e a mosca varejeira, Chrysomya megacephala (F.). $\mathrm{O}$ bioensaio de adultos, usando-se aplicação tópica, indicaram que os machos da $M$. domestica eram mais susceptíveis que fêmeas, com $\mathrm{LD}_{50}$ sendo 118 e $177 \mu \mathrm{g} / \mathrm{mosca}$, respectivamente. Foi obtido mais alto $\mathrm{LD}_{50}$ da C. megacephala; $197 \mu \mathrm{g} / \mathrm{mosca}$ para machos e $221 \mu \mathrm{g} / \mathrm{mosca}$ para fêmeas. Moscas vivas de ambas espécies tiveram vida menor após tratamento com eucaliptol. O bioensaio de larvas, usando o "dipping method" no terceiro estágio, mostrou que $M$. domestica foi mais susceptível que $C$. megacephala com seu $\mathrm{LD}_{50}$ sendo 101 e $642 \mu \mathrm{g} / \mu \mathrm{l}$, respectivamente. A emergência de adultos, que tinham sido tratados com eucaliptol na larva diminuiu somente na $M$. domestica. Tendo propriedade volátil, fumigação ou teste do papel impregnado por eucaliptol ou a eficácia de repelência ou de atração merecem investigações posteriores para aumentar a eficácia do bio-inseticida.

\section{ACKNOWLEDGMENT}

We thank Somsak Piangjai and Tarinee Chaiwong for their assistance. We are indebted to the Faculty of Medicine Endowment Fund, Faculty of Medicine, Chiang Mai University, for financial support.

\section{REFERENCES}

1. BLUST, M.H. \& HOPKINS, T.L. - Olfactory responses of a specialist and generalist grasshopper to volatiles of Artemisia ludoviciana Nuft (Asteraceae). J. chem. Ecol., 13: $1893-1902,1987$

2. BROWN, A.W.A. \& PAL, R. - Insecticide resistance in arthropods. 2. ed. Geneva, World Health Organization, 1971.

3. EL-SHAZLY, M.M.; NASSAR, M.I. \& EL-SHERIEF, H.A. - Toxic effect of ethanolic extract of Nerium oleander (Apocynaceae) leaves against different developmental stages of Muscina stabulans (Diptera-Muscidae). J. Egypt. Soc. Parasit., 26: 461473, 1996.

4. GREENBERG, B. - Flies and disease. Biology and disease transmission. Princeton, Princeton University Press, 1973. v. II. 
5. HINK, W.F. \& FEE, B.J. - Toxicity of D-limonene, the major component of citrus peel oil, to all life stages of the cat flea, Ctenocephalides felis (Siphonaptera: Pulicidae). J. med. Entomol., 23: 400-404, 1986.

6. INDER PAL, S. \& HIDEO, E. - Biological activity of phloroglucinol derivertives from Eucalyptus spp. Nat. prod. Sci., 3: 1-7, 1997.

7. KURAHASHI, H. \& CHOWANADISAI, L. - Blow flies (Insecta: Diptera: Calliphoridae) from Indochina. Species Diver., 6: 185-242, 2001.

8. LAMIRI, A.; LHALOUI, S.; BENJILALI, B. \& BERRADA, M. - Insecticidal effects of essential oils against Hessian fly, Mayetiola destructor (Say). Field crops Res., 71: 9-15, 2001.

9. LAURENT, D.; VILASECA, L.A.; CHANTARAINE, J. et al. - Insecticidal activity of essential oils on Triatoma infestans. Phytother. Res., 11: 285-290, 1997.

10. LEE, S.; PETERSON, C.J. \& COATS, J.R. - Fumigation toxicity of monoterpenoids to several stored product insects. J. stored Prod. Res., 39: 77-85, 2003.

11. MATSUMURA, F. - Toxicology of insecticides. New York and London, Plenum Press, 1985

12. MAUGH, T. H. - To attract or repel, that is the question. Science, 218: $278,1982$.

13. NDIEQIE, I.O.; BUDENBURGE, W.J.; OFENO, D.O. \& HASSANALI, A. - 1,8-cineole, an attractant for the banana weevil, Cosmopolites sordidus. Phytochemistry, 42: 369-371, 1996.

14. PRATES, H.T.; SANTOS, J.P.; WAQUIL, J.M. et al. - Insecticidal activity of monoterpenes against Rhyzopeertha dominica (F.) and Tribolium castanaeum (Herbst). J. stored Prod. Res., 34: 243-249, 1998.

15. RICE, P.J. \& COATS, J.R. - Insecticidal properties of several monoterpenoids to the house fly (Diptera: Muscidae), red flour beetle (Coleoptera: Tenebrionidae), and southern corn rootworm (Coleoptera: Chrysomelidae). J. econ. Entomol., 87: 11721179,1994
16. ROBACKER, D.C. - Specific hunger in Anastrepha ludens (Dipt. Tephritidae): effects on attractiveness of proteinaceous and fruit derived lures. Environ. Entomol., 20: 1680-1686, 1991.

17. SAITO, K.; MOTOYAMA, N. \& DAUTERMAN, W.C. - Effect of synergists on the oral and topical toxicity of azamethiphos to organophosphate-resistant houseflies (Diptera: Muscidae). J. econ. Entomol., 85: 1041-1045, 1992.

18. SHOUKRY, I.F. - Toxicological deteriorations of two volatile oils of Matricaria chamomilla and Clerodendron inerme on the adult house fly Musca domestica L. J. Egypt. Soc. Parasit., 27: 893-904, 1997.

19. SUKONTASON, K.; BUNCHOO, M.; KHANTAWA, B. et al. - Musca domestica as a mechanical carrier of bacteria in Chiang Mai, North Thailand. J. vector Ecol., 25: 114-117, 2000.

20. TRIPATHI, A.K.; PRAJAPATI, V.; AGGARWAL, K.K. \& KUMAR, S. - Toxicity, feeding deterrence, and effect of activity of 1,8-cineole from Artemisia annua on progeny production of Tribolium castanaeum (Coleoptera: Tenebrionidae). J. econ. Entomol. 94: 979-983, 2001.

21. TUMRASVIN, W. \& SHINONAGA, S. - Studies on medically important flies in Thailand III. Report of species belonging to the genus Musca Linne, including the taxonomic keys (Diptera: Muscidae). Bull. Tokyo Med. Dent. Univ., 24: 209-218, 1997.

22. WORLD HEALTH ORGANIZATION - Resistance of vectors of diseases to pesticides. Wld. Hlth. Org. techn. Rep. Ser., (655), 1980.

23. ZUMPT, F. - Myiasis in man and animals in the old world. London, Butterworth, 1965.

Received: 19 January 2004

Accepted: 19 February 2004 